\author{
Aleksandra Todorović - Dudić \\ Mile Stanišić ${ }^{2}$ \\ Veselin Perović ${ }^{3}$
}

\author{
JEL: M21, D81 \\ DOI: $10.5937 /$ industrija45-11003 \\ UDC: 005.591.1:334.713 \\ 005.584 .1 \\ Original Scientific Paper
}

\title{
Contribution of controlling to business efficiency
}

\author{
Article history: \\ Received: 25 May 2016 \\ Sent for revision: 17 June 2016 \\ Received in revised form: 7 February 2017 \\ Accepted:7 February 2017 \\ Available online: 5 April 2017
}

Abstract: The authors of the paper analyse the contribution of controlling to enterprise efficiency. Controlling is an approach that helps companies focus on creating value and driving value creation, quality increase and cost reduction. On the basis of a representative sample of industrial-sector companies in Serbia, the authors conducted a multivariate analysis of variance (MANOVA), discriminant analyses and other parametric procedures and methods. Univariate procedures applied are the Roy's test, Pearson's contingency coefficient $(\chi)$ and the multiple correlation coefficient $(R)$. As a result, the difference in controlling among enterprises relating to identification of controlling contribution to enterprise efficiency is determined. The existence of a boundary is confirmed. As a clear boundary between controlling processes in enterprises is defined, their characteristics are also determined.

Keywords: contribution of controlling, enterprise management, business success, business risk identification, decision making.

\section{Doprinos kontrolinga efikasnosti poslovanja}

Apstrakt: Autori ovog rada analiziraju doprinos kontrolinga efikasnosti preduzeća. Kontroling je pristup koji pomaže kompanijama da se fokusiraju na stvaranje i pokretanje vrednosti, podizanje kvaliteta i smanjenje troškova. $\mathrm{Na}$ bazi reprezentativnog uzorka privrednih društava $u$ industrijskom sektoru $u$ Srbiji, autori su primenili multivarijante analize varijanse (MANOVA),

\footnotetext{
${ }^{1}$ University Business Academy Novi Sad, Faculty of Economics and Engineering, Serbia, aleksandra.todorovicdudic@gmail.com

${ }^{2}$ Singidunum University, Economic Faculty Belgrade

${ }^{3}$ University of Novi Sad, Faculty of Technical Sciences Novi Sad 
diskriminativne analize $i$ drugih parametrijskih postupaka $i$ metoda. Od univarijantnih postupaka primenjen je Roy-ev test, Pirsonov koeficijent kontingencije $(\chi)$ i koeficijent multiple korelacije $(R)$. Kao rezultat istraživanja utvrđena je razlika između kontrolinga u preduzećima u odnosu na identifikaciju doprinosa kontrolinga efikasnosti preduzeća. Egzistencija granice je potvrđena. Kako je jasno definisana granica između nekih kontrolinga u preduzeću određene su i njihove karakteristike.

Ključne reči: doprinos kontrolinga, upravljanje preduzećem, uspešnost poslovanja, identifikacija rizika poslovanja, donošenje odluka.

\section{Introduction}

The purpose and primary goal of controlling in an enterprise is to enable its management to manage its business performance in terms of attainment of anticipated business objectives. This implies the elimination of a possibility of biased decisions of management in the management process.

In the present-day business world, a well organized and positioned controlling reduces operating risks. In addition to that, controlling has an equal impact on any industrial system irrespective of what activity it is involved in.

At the operating level, the controlling process is to ensure the efficiency of individual processes and appropriate utilization of resources needed to conduct a process. The operational process of controlling overlaps with the process of operations management, as both serve the same purpose: maintenance of operating efficiency of a process.

This research in controlling predominantly aims to help evaluate the quality of the judgements and decisions made within an organization, examine the determinants of decision quality, and report on the efficacy of factors that enable improvement of judgement and decision-making. Such research provides useful insights into the benefits of controlling practices that are intended to support the decision-making within an organization. The research in controlling also helps determine the extent to which controlling practices actually motivate individuals within an organization and help mitigate the divergence of interests between employees and owners.

Back in the past, a more elaborated advocacy of the use of controlling or budgetary control for management purposes emerged in a number of articles published in the mid-1920's, and the ICWA's fourth National Costing Conference in 1925 was devoted entirely to that topic (Perry-Keene,1925).

A strong position of controlling in economic practice was simultaneously affirmed by the results of two empirical researches which show that in Poland 
and Croatia. The one in Poland shows that controlling has become one of the most frequently implemented management methods (Bienkowska, 2013). Between 2011 and 2013, Bienkowska, A., performed her own studies among 310 organizations operating in Poland. $58,4 \%$ of them implemented controlling. The research tool was a questionnaire filled in by one competent person in each of the surveyed organizations. The respondents were asked to respond to statements in a questionnaire using a five-point Likert scale (1-5, "from Definitely no" to "Definitely yes"). Controlling is characterized by high effectiveness, and therefore it directly contributes to the increase of, first and foremost, the management efficiency, but also to the effectiveness of the organization as a whole.

The most prominent contribution to the development of controlling in our region is a research conducted in Croatia (Vuko,Ojvan, 2013). The population from which the sample is drawn represents the companies listed on the regulated market of the Zagreb Stock Exchange. This population was selected because it is assumed that there is a high probability that such companies have a controlling department. The survey questionnaire was carried out from March to June 2012. The questionnaires were sent and returned by e-mail. Out of 176 questionnaires sent, 39 were returned (the response rate was $22,6 \%$ ). The initial analysis of the results showed that 30 companies $(76,9 \%)$ had a controlling department, while 9 companies $(23,1 \%)$ didn't have a controlling department. It was measured by a Likert scale, where 1 meant that controlling was not effective and 5 meant that controlling was very effective. The majority of respondents answered that controlling was effective $(46,7 \%)$ and very effective $(30 \%)$. The aim of that paper was to investigate the effectiveness of a controlling function in Croatian listed companies and the characteristics of controlling that contribute to business efficiency. Overall, the results of the research indicate that effective controlling has positive effects on business efficiency.

The key issue, as well as the entire way of addressing it in this research relate to the analysis of the thematic unit identification of contribution of controlling to operating efficiency relating to controlling in enterprises. Accordingly, the following operating tasks of the research are set:

- to present basic parameters of identification of controlling contribution to enterprise relating to enterprise controlling,

- to determine differences between controlling in enterprises relating to identification of controlling contribution to enterprise efficiency,

- to define characteristics of each enterprise controlling relating to identification of controlling contribution to business efficiency,

- to determine the homogeneity of each enterprise controlling relating identification of controlling contribution to business efficiency, 
- to determine the contribution of attributes to the characteristics of each enterprise controlling relating to identification of controlling contribution to business efficiency,

- to determine the contribution of the whole to the characteristics.

Taking into account previous experiences, the core of the issue, subject and aims of the research, as well as the methodological approach to this research, the following hypotheses may be put:

The principal research hypothesis is as follows:

$\mathrm{H}_{0} \quad$ There is no difference in controlling in enterprises relating to identification of controlling contribution to business efficiency;

$A_{0} \quad$ There is a difference in controlling in enterprises relating to identification of controlling contribution to business efficiency.

Other hypotheses are as follows:

$\mathrm{H}_{1} \quad$ There is no difference in enterprise controlling (relating to identification of controlling contribution to business efficiency);

$A_{1} \quad$ There is a difference in enterprise controlling (relating to controlling contribution to business efficiency);

$\mathrm{H}_{2} \quad$ There is no clearly defined boundary between controlling in enterprises (relating to contribution to business efficiency);

$\mathrm{A}_{2} \quad$ There is clearly defined boundary between controlling in enterprises (relating to contribution to business efficiency);

$\mathrm{H}_{3} \quad$ There is no difference in enterprise controlling in terms of certain attributes of organization identification (relating to identification of controlling contribution to business efficiency);

$\mathrm{A}_{3} \quad$ There is a difference in enterprise controlling in terms of certain attributes of organization identification (relating to identification of controlling contribution to business efficiency);

$\mathrm{H}_{4} \quad$ There is no significant difference between any two subsamples of enterprise controlling - there is controlling and there is no controlling (relating to identification of controlling contribution to business efficiency).

$\mathrm{A}_{4} \quad$ There is a significant difference between any two subsamples of enterprise controlling - there is controlling and there is no controlling (relating to identification of controlling contribution to business efficiency).

\section{Research methodology}

This paper is based on a conceptual analysis and conclusions drawn from the literature on the general review of controlling-related papers. 
The questionnaire method is applied as there is no other way of collating both internal data and information on companies and those they are obliged to make public. The questionnaire on the basis of which the research was conducted is divided into two parts. The first, general part, consists of 6 questions relating to information on the company included in the survey. The other part of the questionnaire relates to the very organization and activities of the controlling department within the subject enterprise from September 2014 to February 2015. The questionnaire was e-mailed to 150 enterprises in Serbia involved different prevailing activities. Out of that number, 51 enterprises replied, which is a response rate of $34 \%$. Each enterprise was supposed to give only one answer. It is measured by a Likert scale, where 1 is "definitely disagree" and 5 is "definitely agree". The targeted core group included organizations for which it was assumed with a great probability that they had a controlling function within their organizational structure. It is important to point out that a controlling function is a segment that may or may not be incorporated in an organizational structure, and the aim of this research was to identify organizations with controlling in an organizational and institutional sense.

The observed variances are attributes (or variables). The attributes on the basis of which the sample is divided into subsamples are criterion attributes. Several attributes that are meaningfully linked and make a logical whole are referred to simply as the "whole" (space). All observed thematic wholes make the research space.

\subsection{The research sample}

The analysis was conducted on a sample of 51 enterprises in Serbia, dividied into 2 subsamples with reference to enterprise controlling. The subsamples are: enterprises with the implemented controlling as an organizational unit (42) and enterprises without the implemented controlling (9).

\subsection{The research space}

The space of this research referred to as identification of contribution of controlling to business efficiency is made up of the following: controlling does not contribute to better business performance, evaluation of controlling contribution to business management efficiency, implementation of controlling eliminates biased management decisions, controlling enables identification of operating risks. A difference with regard to the controlling in enterprise criterion will be analysed. 


\subsection{Mathematical and statistical data processing}

Data were processed by applying appropriate mathematical and statistical procedures. The applied procedures and their sequence of application are important in the research. Efforts were made to lose as little information obtained in the course of the research as possible. The sequence of the application of procedures is of extreme importance, both for drawing conclusions and for a timely elimination and inclusion of certain attributes to render a better quality of the research. The analysis is made in two steps and they are: testing hypotheses on similarity and difference and determining the degree of differences by defining characteristics.

\subsection{Procedures applied}

The attribute of the entirety of enterprise, identification of contribution of controlling to business efficiency has nonparametric properties and accordingly will be analysed by applying nonparametric procedures by modality frequency.

In order to avoid losing information, data are scaled on contingency tables by seeking the finest relationships and findings on nonparametric magnitudes. By this procedure, based on frequency, each class is assigned an actual number. The fact that it is possible to apply scale-related procedures to scale values indicates that, this way, new findings are obtained in the research which would not be possible by applying nonparametric scale-related procedures and methods. Data scaling does not exclude the application of nonparametric tests. On the basis of the previously said it can be seen that it is possible to apply a MANOVA, discriminant analysis and other parametric procedures and methods to the scaled data. Univariate procedures to be applied are the Roy's test, Pearson's contingency coefficient $(\chi)$, and multiple correlation coefficient $(\mathrm{R})$.

The application of procedures on the basis of which a measure is obtained adds a new dimension to the research. By calculating the discrimination coefficient, features defining the distinctiveness of subsamples and features that need to be excluded from further processing are singled out, i.e. the space under observation is reduced. Presentation of the evaluation of subsamples homogeneity and the distance between them is aimed at examining the observed manifestation to a greatest possible extent.

The purpose of application of mathematical and statistical analysis is to determine properties of each subsample, homogeneity and distance between them in comparison to the derived properties in order to make a reliable and precise prediction and a forecast of certain reliability. 


\subsection{Hypothesis testing}

The procedures used in proving the existence of similarities or differences between the subsamples either confirm the similarity hypothesis or reject it (favour the alternative hypothesis), i.e. indicate the existence of differences. In testing hypothesis, the critical $p$ value is used, which is a conclusion risk. If $p$ $>0.100$, there is no reason to accept the initial hypothesis. Two significance thresholds are used to reject the initial hypothesis. In the case of $0.10>p>$ 0.05 , the alternative hypothesis with a higher conclusion risk is accepted. When $p<0.05$, the alternative hypothesis is accepted and it is stated that there are two significant differences.

The hypotheses for the applied procedures are defined in the following way:

- $\quad$ the MANOVA procedure tests the $\mathrm{H}_{1}$, hypothesis, which is:

$\mathrm{H}_{1}$ There are no significant differences between the subsamples of the observed thematic whole.

$A_{1}$ There are significant differences between some subsamples of the observed thematic whole.

- The discriminant analysis procedure tests the $\mathrm{H}_{2}$ hypothesis:

$\mathrm{H}_{2}$ There is no clearly defined boundary between the subsamples of the observed thematic whole.

$\mathrm{A}_{2}$ There is a clearly defined boundary between some subsamples of the observed thematic whole.

- the ANOVA or Roy's test procedures are used to test the $\mathrm{H}_{3}$ hypothesis:

$\mathrm{H}_{3}$ There is no significant difference between subsamples when certain attributes are concerned.

$\mathrm{A}_{3}$ There is a significant difference between some subsamples when certain attributes are concerned.

\section{Results of the Research}

In line with the research goals, methodological approach and hypotheses set in this research, the difference within the thematic whole identification of contribution of controlling to business efficiency will be analysed with regard to controlling in enterprises and existence of controlling. On the basis of the analyses applied, attributes of each subsample will be determined, as well as the distance between them in order to calculate the effects of attributes and effects of the thematic whole on the characteristics. 
Todorović-Dudić A. et al.: Contribution of controlling to business efficiency

\subsection{Analysis of identification of contribution of controlling to business efficiency relating to controlling in enterprise}

In accordance with the previously defined draft research and with regard to enterprise controlling, the thematic unit identification of contribution of controlling to business efficiency is analysed. In part one, the numerical and percentage frequency of modalities of the analysed parameters of enterprise controlling is presented. In part two, the difference in controlling in enterprises is analysed, i.e. the hypothesis is proven or rejected in order to evaluate the obtained results and appropriateness of further examination and to define directions and methodological priorities in their processing. Following this, characteristics of each enterprise controlling are defined and the distance and homogeneity between them is determined. The analysis of the thematic unit identification of contribution of controlling to business efficiency is conducted i.e.: controlling does not contribute to business performance, evaluation of controlling contribution to operations management efficiency, controlling implementation excludes biased management decisions and controlling enables identification of operating risk. It is conducted on a sample of 51 enterprises, comprised of 2 subsamples, i.e.: there is controlling (42) and there is no controlling (9). Each unit has several modalities, so that: "controlling does not contribute to business performance" has 5 modalities and they are: Do not agree at all, Mainly do not agree, Agree partly, Mainly agree, Agree fully. The evaluation of controlling contribution to operating efficiency has 5 modalities and they are: one, two, three, four and five. Implementation of controlling excludes biased management decisions has 5 modalities: Do not agree at all, Mainly do not agree, Agree partly, Mainly agree, Agree fully. Controlling enables identification of operating risk has 5 modalities: Do not agree at all, Mainly do not agree, Agree partly, Mainly agree, Agree fully.

\subsubsection{Review of frequency of identifications of contribution of controlling to business efficiency when enterprise controlling is concerned}

The tables given below present results in numerical form (n) and as percentage (\%): controlling does not contribute to business performance, evaluation of contribution of controlling to business efficiency, controlling implementation excludes biased management decisions and controlling enables identification of operating risk, and the attention is shifted to significant differences between and within the levels. With the descriptive procedure it is possible only to hint some features of certain levels of identification of contribution of controlling to business efficiency. 
Todorović-Dudić A. et al.: Contribution of controlling to business efficiency

Table 1 Frequency expressed numerically (n) and as percentage (\%): controlling does not contribute to business performance when controlling in enterprise is concerned

\begin{tabular}{|c|c|c|c|c|c|c|c|c|c|c|}
\hline & \multicolumn{2}{|c|}{$\begin{array}{c}\text { Do not agree } \\
\text { at all }\end{array}$} & \multicolumn{2}{|c|}{$\begin{array}{l}\text { Mainly do not } \\
\text { agree }\end{array}$} & \multicolumn{2}{|c|}{$\begin{array}{l}\text { Agree } \\
\text { partly }\end{array}$} & \multicolumn{2}{|c|}{$\begin{array}{l}\text { Mainly } \\
\text { agree }\end{array}$} & \multicolumn{2}{|c|}{$\begin{array}{l}\text { Agree } \\
\text { fully }\end{array}$} \\
\hline & $\mathrm{n}$ & $\%$ & $\mathrm{n}$ & $\%$ & $n$ & $\%$ & $\mathrm{n}$ & $\%$ & $n$ & $\%$ \\
\hline $\begin{array}{l}\text { There is } \\
\text { controlling }\end{array}$ & 32. & $76.2^{*}$ & 5. & 11.9 & 3. & 7.1 & 1. & 2.4 & 1. & 2.4 \\
\hline $\begin{array}{l}\text { There is no } \\
\text { controlling }\end{array}$ & 4. & 44.4 & 1. & 11.1 & 1. & 11.1 & 0. & .0 & 3. & 33.3* \\
\hline
\end{tabular}

Source: the authors' research

When analyzing the table shown (1), it can be seen that within the subsample there is controlling, the most frequent modality is "Do not agree at all" which makes 32 enterprises $(76.2 \%)$ out of the total of 42 , which is significantly above "Mainly do not agree" (5 enterprises, $11.9 \% \mathrm{p}=.000$ ), followed by "Agree partly" (3 enterprises, 7.1\% p=.000), "Mainly agree" ( 1 enterprise, $2.4 \% \mathrm{p}=.000$ ), "Agree fully" (1 enterprise, $2.4 \% \mathrm{p}=.000$ ). In the case of the subsample there is no controlling, the frequency of "Do not agree at all" (4 enterprises, $44.4 \%)$ is significantly above the frequency of "Mainly agree" $(0$ enterprises, $.0 \% \mathrm{p}=.036$ ).

The difference in controlling in enterprises: within Do not agree at all, the most frequent is "there is controlling" $(76.19 \%)$, which is significantly more frequent than "there is no controlling" (44.44\% $\mathrm{p}=.064)$, within Mainly do not agree, the most frequent is "there is controlling" (11.90\%), within Agree partly, the most frequent is "there is no controlling" (11.11\%), within Mainly agree, the most frequent is "there is controlling" (2.38\%), and within Agree fully, the most frequent is "there is no controlling" (33.33\%), which is significantly greater than "there is controlling" (2.38\% $\mathrm{p}=.003)$.

On the basis of the obtained results it is possible to single out enterprise controlling characteristics for: controlling does not contribute to business performance, and for there is controlling a more pronounced property is Do not agree at all ${ }^{*}$, whereas for there is no controlling, a more pronounced property is Agree fully*.

As $p=.033 \chi^{2}-$ of the test, it can be said that there is a correlation between enterprise controlling and controlling does not contribute to business performance and the correlation $\chi=.413$ is moderate.

When analyzing the table shown (2) it can be seen that in the case of there is controlling the most frequent is grade five, which comprises 38 enterprises $(90.5 \%)$ out of the total of 42 , and that is significantly higher than the frequency of grades four ( 3 enterprises, $7.1 \%, p=.000$ ), two ( 1 enterprise, 
$2.4 \%, p=.000$ ) and one ( 0 enterprises, $.0 \%, p=.000$ ) respectively. In the case of there is no controlling, the frequency of grade five (7 enterprises, $77.8 \%$ ) is significantly above the frequency of grades one (1 enterprise, $11.1 \%$, $\mathrm{p}=.011$ ), four ( 1 enterprise, $11.1 \%, \mathrm{p}=.011$ ) and two (0 enterprises, $.0 \%$, $\mathrm{p}=.003$ ) respectively.

Table 2 Evaluation of contribution of controlling to business efficiency relating to enterprise controlling expressed numerically $(n)$ and as percentage (\%)

\begin{tabular}{|l|c|c|c|c|c|c|c|c|c|c|}
\hline & \multicolumn{2}{|c|}{ One } & \multicolumn{2}{c|}{ Two } & \multicolumn{2}{c|}{ Three } & \multicolumn{2}{c|}{ Four } & \multicolumn{2}{c|}{ Five } \\
\hline & $\mathrm{n}$ & $\%$ & $\mathrm{n}$ & $\%$ & $\mathrm{n}$ & $\%$ & $\mathrm{n}$ & $\%$ & $\mathrm{n}$ & $\%$ \\
\hline $\begin{array}{l}\text { There is } \\
\text { controlling }\end{array}$ & 0. & .0 & 1. & 2.4 & 0. &. & 3. & 7.1 & 38. & 90.5 \\
\hline $\begin{array}{l}\text { There is no } \\
\text { controlling }\end{array}$ & 1. & $11.1^{*}$ & 0. & .0 & 0. & .0 & 1. & 11.1 & 7. & 77.8 \\
\hline
\end{tabular}

Source: the authors' research

The difference in controlling in enterprises: within grade one "there is no controlling" is more frequent (11.11\%), which is significantly above "there is controlling" $(.00 \% \mathrm{p}=.034)$, within grade two, "there is controlling" prevails (2.38\%), within grade four, "there is no controlling" prevails $(11.11 \%)$, and within grade five, "there is a controlling" prevails (90.48\%).

On the basis of the obtained results, it is possible to specify characteristics of each controlling in enterprises. Thus, when the evaluation of contribution of controlling to business efficiency is concerned, the subsample there is controlling has a slightly pronounced property five, whereas there is no controlling has a more pronounced property one*.

As $p=.160 \chi^{2}-$ of the test, it can be said that there is a correlation between enterprise controlling and the evaluation of contribution of controlling to business management efficiency, and as $\chi=.303$, the correlation is low.

Table 3 Controlling implementation eliminates biased management decisions when enterprise controlling is concerned expressed numerically (n) and as percentage (\%)

\begin{tabular}{|l|c|c|c|c|c|c|c|c|c|c|}
\hline & \multicolumn{2}{|c|}{$\begin{array}{c}\text { Do not } \\
\text { agree at all }\end{array}$} & \multicolumn{2}{c|}{$\begin{array}{c}\text { Mainly do } \\
\text { not agree }\end{array}$} & \multicolumn{2}{c|}{$\begin{array}{c}\text { Agree } \\
\text { partly }\end{array}$} & \multicolumn{2}{c|}{$\begin{array}{c}\text { Mainly } \\
\text { agree }\end{array}$} & \multicolumn{2}{c|}{ Agree fully } \\
\hline & $\mathrm{n}$ & $\%$ & $\mathrm{n}$ & $\%$ & $\mathrm{n}$ & $\%$ & $\mathrm{n}$ & $\%$ & $\mathrm{n}$ & $\%$ \\
\hline $\begin{array}{l}\text { There is } \\
\text { control-ling }\end{array}$ & 0. & .0 & 1. & 2.4 & 0. & .0 & 4. & 9.5 & 37. & $88.1^{*}$ \\
\hline $\begin{array}{l}\text { There is no } \\
\text { controlling }\end{array}$ & 1. & $11.1^{*}$ & 0. & .0 & 4. & $44.4^{*}$ & 1. & 11.1 & 3. & 33.3 \\
\hline
\end{tabular}

Source: the authors' research 
When analyzing the table shown (3), it can be seen that in the case of the subsample there is controlling the most frequent modality is Agree fully, which includes 37 enterprises (88.1\%) out of the total of 42 , which is significantly above the frequency of Mainly agree (4 enterprises, 9.5\%, $\mathrm{p}=.000$ ), Mainly do not agree (1 enterpirse, $2.4 \%, p=.000$ ), Do not agree at all (0 enterprises, .0\%, $\mathrm{p}=.000$ ), Agree partly (0 enterprises, .0\%, $\mathrm{p}=.000$ ) respectively. When the subsample there is no controlling is concerned, the frequency of the modality Agree partly (4 enterprises, $44.4 \%$ ) is significantly higher than the frequency of Mainly disagree ( 0 enterprises, . $0 \%, p=.036$ ).

With regard to the difference in controlling in enterprises, when Do not agree at all is concerned, the most frequent is "there is no controlling" $(11,11 \%)$, which is significantly above the frequency of "there is controlling" $(.00 \%$, $\mathrm{p}=.034$ ), whereas in the case of Mainly do not agree the most frequent is "there is controlling" (2.38\%), in the case of Agree partly the most frequent is "there is no controlling" (44.44\%), which is significantly higher than the frequency of "there is controlling" $(.00 \%, \mathrm{p}=.000)$, and in the case of Mainly agree, the most frequent is "there is no controlling" (11.11\%), whereas in the case of Agree fully, the most frequent is "there is controlling" $(88.10 \%)$, which is significantly higher than the frequency of "there is no controlling" $(33.33 \%$, $\mathrm{p}=.001$ ).

On the basis of the obtained results, it is possible to specify the characteristics of each enterprise controlling with regard to: implementation of controlling eliminates biased management decisions, which is that there is controlling has a more pronounced property Agree fully*, whereas there is no controlling has a more pronounced property Do not agree at all*, Agree partly*.

As $p=.000 \chi^{2}-$ of the test, it can be said that there is a correlation between enterprise controlling and the modality controlling implementation eliminates biased management decisions, and as $\chi=.584$, the correlation is moderate.

Table 4 Controlling enables risk identification relating to enterprise controlling expressed numerically (n) and as percentage (\%)

\begin{tabular}{|l|c|c|c|c|c|c|c|c|c|c|}
\hline & \multicolumn{2}{|c|}{$\begin{array}{c}\text { Do not } \\
\text { agree at all }\end{array}$} & \multicolumn{2}{c|}{$\begin{array}{c}\text { Mainly do } \\
\text { not agree }\end{array}$} & \multicolumn{2}{c|}{$\begin{array}{c}\text { Agree } \\
\text { partly }\end{array}$} & \multicolumn{2}{c|}{$\begin{array}{c}\text { Mainly } \\
\text { agree }\end{array}$} & \multicolumn{2}{c|}{ Agree fully } \\
\hline & $\mathrm{n}$ & $\%$ & $\mathrm{n}$ & $\%$ & $\mathrm{n}$ & $\%$ & $\mathrm{n}$ & $\%$ & $\mathrm{n}$ & $\%$ \\
\hline $\begin{array}{l}\text { There is a } \\
\text { controlling }\end{array}$ & 0. & .0 & 1. & 2.4 & 0. & .0 & 4. & 9.5 & 37. & $88.1^{*}$ \\
\hline $\begin{array}{l}\text { There is no } \\
\text { controlling }\end{array}$ & 1. & $11.1^{*}$ & 0. & .0 & 1. & $11.1^{*}$ & 3. & $33.3^{*}$ & 4. & 44.4 \\
\hline
\end{tabular}

Source: the authors' research 
When analyzing the table shown (4), it can be seen that the most frequent response for the subsample there is controlling is Agree fully, which is comprised of 37 enterprises (88.1\%) out of the total of 42 , which is significantly above the modality Mainly agree (4 enterprises, 9.5\%, $\mathrm{p}=.000$ ), which is followed by Mainly do not agree (1 enterprise, $2.4 \%, p=.000)$, Do not agree at all ( 0 enterprises, . $0 \%, p=.000$ ), and Agree partly ( 0 enterprises, $.0 \%$, $\mathrm{p}=.000$ ). In the case of there is controlling, the frequency of Agree fully (4 enterprises, $44.4 \%$ ) is significantly higher than the frequency of Mainly do not agree ( 0 enterprises, $.0 \%, p=.036$ ).

With regard to the difference in controlling in enterprises, when Do not agree at all is concerned, "there is no controlling" $(11.11 \%)$ is more frequent, which is significantly higher than "there is controlling" $(.00 \% \mathrm{p}=.034)$, whereas in the case of Mainly do not agree, "there is controlling" (2.38\%) is more frequent; in the case of Agree partly, "there is no controlling" (11.11\%) is more frequent, which is significantly higher than the frequency of "there is controlling" $(.00 \%, \mathrm{p}=.034)$; in the case of Mainly agree, "there is no controlling" (33.33\%) is more frequent, which si significantly higher than the frequency of "there is controlling" $(9.52 \%, p=.065)$, whereas in the case of Agree fully, "there is controlling" $(88.10 \%)$ is more frequent, which is significantly higher than the frequency of "there is no controlling" $(44.44 \%$, $\mathrm{p}=.004$ ).

On the basis of the obtained results, it is possible to specify the characteristics of each enterprise controlling with regard to: controlling enables operating risk identification, which is that the subsample there is controlling has a more pronounced property Agree fully*, whereas there is no controlling has a more pronounced property Do not agree at all *, Agree partly*.

As $p=.006 \chi^{2}-$ of the test, it can be said that there is a correlation between enterprise controlling and the statement controlling enables identification of business risk, and as $\chi=.469$, the correlation is moderate.

\subsubsection{Analysis of differences in enterprise controlling with regard to identification of controlling contribution to business efficiency}

In this chapter, the statement that there is a significant difference in controlling in enterprises with regard to identification of controlling contribution to business efficiency will be either proven or rejected. 
Todorović-Dudić A. et al.: Contribution of controlling to business efficiency

Table 5.Significance of the difference in enterprise controlling with regard to identification of contribution of controlling to business efficiency

\begin{tabular}{|l|c|c|c|}
\hline ANALYSIS & $\mathrm{n}$ & $\mathrm{F}$ & $\mathrm{p}$ \\
\hline MANOVA & 4 & 21.563 & .000 \\
\hline Discriminant & 4 & 21.563 & .000 \\
\hline
\end{tabular}

Source: the authors' research

On the basis of value $p=.000$ (MANOVA analysis) and $p=.000$ (discriminant analysis), the hypothesis is accepted. It is also accepted that there is a difference and a clearly defined boundary between controlling in enterprises.

Table 6. Significance of the difference in enterprise controlling relating to identification of contribution of controlling to business efficiency

\begin{tabular}{|l|c|c|c|c|c|}
\hline & $\chi$ & $\mathrm{R}$ & $\mathrm{F}$ & $\mathrm{p}$ & $\mathrm{c} . \mathrm{dsc}$ \\
\hline $\begin{array}{l}\text { Does not contribute to better business } \\
\text { performance }\end{array}$ & .413 & .453 & 12.154 & .001 & .801 \\
\hline Evaluation of controlling contribution & .303 & .318 & 5.297 & .026 & .018 \\
\hline Excludes biased business decisions & .584 & .719 & 50.441 & .000 & .973 \\
\hline Controlling identifies operating risk & .469 & .531 & 18.430 & .000 & .000 \\
\hline
\end{tabular}

Source: the authors' research

Legend: $c . d s c$. is the discrimination coefficient

With $p<.1$, there is a significant difference in controlling in enterprises with regard to: controlling does not contribute to business performance (.001), evaluation of controlling contribution to business efficiency (.026), implementation of controlling eliminates biased management decisions $(.000)$ and controlling enables identification of business risks (.000).

The discrimination coefficients indicate that the biggest discrimination in controlling in enterprises is in the case of identification of contribution of controlling to business efficiency, i.e. that the biggest difference is in the case of: implementation of controlling eliminates biased management decisions (.973), controlling does not contribute to better business performance (.801), evaluation of controlling contribution to efficiency of enterprise management (.018) and controlling enables identification of business risk (.000). 
Todorović-Dudić A. et al.: Contribution of controlling to business efficiency

\subsubsection{Characteristics and homogeneity of enterprise controlling with regard to identification of contribution of controlling to business efficiency}

Table 7.Characteristics and homogeneity of enterprise controlling with regard to identification of contribution of controlling to business efficiency

\begin{tabular}{|c|c|c|c|}
\hline & $\begin{array}{l}\text { There is } \\
\text { controlling }\end{array}$ & There is no controlling & $\begin{array}{c}\text { Contr. } \\
\%\end{array}$ \\
\hline $\begin{array}{l}\text { Elimination of biased } \\
\text { business decisions }\end{array}$ & Agree fully* & $\begin{array}{r}\text { Do not agree at all }{ }^{*} \text { Agree } \\
\text { partly }\end{array}$ & 54.297 \\
\hline $\begin{array}{l}\text { Does not contribute to } \\
\text { business performance }\end{array}$ & $\begin{array}{r}\text { Do not agree } \\
\text { at all }\end{array}$ & Agree fully * & 44.699 \\
\hline $\begin{array}{l}\text { Evaluation of controlling } \\
\text { contribution }\end{array}$ & & one $^{*}$ & 1.004 \\
\hline $\begin{array}{l}\text { Controlling identifies } \\
\text { operating risk }\end{array}$ & Agree fully ${ }^{*}$ & $\begin{array}{r}\text { Do not agree at all }{ }^{*} \text { Agree } \\
\text { partly *, Mainly agree }\end{array}$ & .000 \\
\hline $\mathrm{n} / \mathrm{m}$ & $41 / 42$ & $7 / 9$ & \\
\hline$\%$ & 97.62 & 77.78 & \\
\hline
\end{tabular}

Source: the authors' research

hmg - homogeneity; contr. \% - contribution of attributes to characteristics

The property of each controlling subsample in enterprise is mostly defined by "implementation of controlling eliminates biased management decisions" as the contribution of the attribute to characteristics is $54.30 \%$, which is followed by controlling does not contribute to better business performance (44.70\%). Homogeneity in the case of there is controlling is $97.62 \%$ and in the case of there is no controlling it is $77.78 \%$.

On the basis of the previously stated, it can be said that 41 out of 42 enterprises have characteristics "there is controlling" and homogeneity is $97.6 \%$ (greater), meaning that 1 enterprise has other characteristics and not the characteristics of its group. In addition to that, the "there is no controlling" characteristics have 7 out of 9 enterprises and homogeneity is $77.8 \%$ (greater) as 2 enterprises have other characteristics.

That means that for enterprises the characteristics of which are similar to those of "there is controlling" although it is not known if they have controlling, it can be expected with a $97.6 \%$ confidence that they belong to the "there is controlling" group, i.e. it is possible to give a forecast with a certan reliability.

On the basis of "identification of contribution of controlling to business efficiency" it can be said that: 
- "there is controlling" has the following properties: for controlling implementation eliminates biased management decision, it is Agree fully*, for controlling does not contribute to better business performance, it is Do not agree at all ${ }^{*}$, for evaluation of controlling contribution to enterprise management efficiency, it is -, and for controlling enables business risk identification, it is je Agree fully*.

- "there is no controlling" has the following properties: for controlling implementation eliminates biased management decisions, it is Do not agree at all*, Agree partly*, for controlling does not contribute to better business performance, it is Agree fully*, for evaluation of controlling contribution to business efficiency, it is one* and for controlling enables business risk identification, it is Do not agree at all ${ }^{*}$, Agree partly*, Mainly agree*.

Table 1.The distance (Mahalanobis) between controlling in enterprises with regard to identification of contribution of controlling to business efficiency

\begin{tabular}{|c|c|c|}
\hline & There is controlling & There is no controlling \\
\hline There is controlling & .00 & 3.52 \\
\hline There is no controlling & 3.52 & .00 \\
\hline
\end{tabular}

Source: the authors' research

By determining the Mahalanobis distance between controlling in enterpirses another indicator of similarities or differences is obtained. Distances of different spaces can be compared. The distances in the table indicate that the distance between enterprise controlling in subsamples: there is controlling and there is no controlling in enterprise is greater.

\section{Discussion of results}

The subject matter of the analysis is the difference in enterprise controlling with regard to identification of contribution of controlling to business efficiency.

The difference in controlling in enterprises is determined in the following cases: identification of controlling contribution to business efficiency (.000), implementation of controlling eliminates biased management decisions (.000), controlling enables identification of business risk (.001), and evaluation of contribution of controlling to business efficiency (.026). The existence of a boundary (.000) is confirmed for: implementation of controlling eliminates biased management decisions, controlling does not contribute to better business performance, evaluation of controlling contribution to business management efficiency and controlling enables business risk identification. 
By observing only the results relating to enterprise controlling, it is noticed that the contribution of the entirety of identification of controlling contribution to business efficiency to the characteristics $11.610 \%$.

As with identification of controlling contribution to business efficiency there is a clearly defined boundary between certain controlling functions in enterprises, it is possible to determine their characteristics.
Table 9. Characteristics and contribution of attributes to the characteristics of controlling relating to identification of controlling contribution to business efficiency

\begin{tabular}{|c|c|c|c|}
\hline & $\begin{array}{l}\text { There is } \\
\text { controlling } \\
\end{array}$ & There is no controlling & contr \% \\
\hline $\begin{array}{l}\text { Elimination of biased } \\
\text { business decisions }\end{array}$ & Agree fully ${ }^{\star}$ & $\begin{array}{r}\text { Do not agree at all }{ }^{*}, \begin{array}{c}\text { Agree } \\
\text { partly }\end{array} \\
\end{array}$ & 54.30 \\
\hline $\begin{array}{l}\text { Does not contribute to better } \\
\text { business performance }\end{array}$ & $\begin{array}{r}\text { Do not agree } \\
\text { at all } \\
\end{array}$ & Agree fully* & 44.70 \\
\hline \begin{tabular}{|l|} 
Evaluation od controlling \\
contribution
\end{tabular} & & one $^{*}$ & 1.00 \\
\hline $\begin{array}{l}\text { Controlling identifies } \\
\text { business risk }\end{array}$ & Agree fully* & $\begin{array}{r}\text { Do not agree at all }{ }^{*}, \text { Agree } \\
\text { partly }{ }^{*}, \text { Mainly agree }\end{array}$ & .00 \\
\hline $\mathrm{hmg} \%$ & 97.62 & 77.78 & \\
\hline
\end{tabular}

Source: the authors' research

hmg - homogeneity; contr - contribution of attribute to characteristics.

The property of each subsample of enterprise controlling is mainly defined by implementation of controlling eliminates biased management decisions, as the contribution of attribute to characteristics is $54.30 \%$, which is followed by controlling does not contribute to better business performance (44.70\%), evaluation of controlling contribution to business management efficiency $(1.00 \%)$ and controlling enables operating risk identification (.00\%). Homogeneity is $97.62 \%$ in the case there is controlling and $77.78 \%$ in the case there is no controlling.

On the basis of identification of controlling contribution to business efficiency, it can be said that:

- there is controlling has the following values: implementation of controlling eliminates biased decisions of management - Agree fully*; controlling does not contribute to better business performance - Do not agree at all*; evaluation of controlling contribution to enterprise management efficiency -; controlling enables operating risk identification - Agree fully*; and the homogeneity is $97.62 \%(41 / 42)$. 
- there is no controlling has the following values: implementation of controlling eliminates biased decisions of management - Do not agree at all ${ }^{*}$, Agree partly*; controlling does not contribute to better business performance Agree fully*; evaluation of controlling contribution to business management efficiency - one*; controlling enables operating risk identification - Do not agree at all ${ }^{*}$, Agree partly* Mainly agree*; and the homogeneity is $77.78 \%$ (7/9).

The aim of this paper was to investigate the effectiveness of controlling function in Serbian companies and the characteristics of controlling that contribute to business efficiency. Overall, results of the research indicate that effective controlling has positive effects on business efficiency. These results support studies undertaken in Poland and Croatia. However, the analysis in this paper is limited in several ways and many other aspects of the issue can be investigated in the future. The main limitation of our research is a rather small sample of companies that participated in it. A larger simple size would provide a more explanatory power and greater confidence in findings.

\section{Conclusion}

The discussion on controlling effectiveness can serve, on the one hand, as grounds to reject the quality of the controlling service. On the other hand, however, it can be an indicator used for the evaluation of controlling solutions which have been implemented in the organization, confirming their correctness and drawing up programmes that develop such solutions.

In this paper, the analysis of enterprise controlling is made on the sample of 51 enterprises in Serbia, taken out of a population, defined as a population and divided into 2 subsamples (there is controlling and there is no controlling).

In accordance with the previously set goals of the research, the methodological approach and hypotheses put, this research analyses the difference in controlling in enterprises relating to the identification of contribution of controlling to business efficiency.

On the basis of the obtained results and their interpretation, the following conclusion can be drawn:

In the case of identification of contribution of controlling to business efficiency, the methods applied (MANOVA .000 and discriminant .000) indicate that there is a significant difference in controlling in different enterprises, implementation of controlling eliminates biased management decisions (.000), controlling enables business risk identification (.000), controlling does not contribute to better business efficiency (.001), evaluation of controlling contribution to business management efficiency (.026); with discrimination 
implementation of controlling eliminates biased management decisions (.973), controlling does not contribute to better business performance (.801), evaluation of contribution of controlling to business management efficiency (.018), controlling enables business risk identification (.000).

In this way, controlling is characterized by high effectiveness, and it directly contributes to the increase of management efficiency, as well as to the effectiveness of the organization as a whole.

The effects of controlling implementation and its impact on business success clearly demonstrate that controlling is a necessity. Present and future perspectives, e.g. crisis controlling, project controlling or sustainability controlling upgrade the basic understanding of controlling. This paper contributes to the research of controlling in two ways. Firstly, the results of empirical studies reflect the presence of controlling in the business practice in Serbia, and secondly, the paper provides a current view and future outlook for controlling development. Controlling has indeed become so widely accepted that it is worth researching more deeply. International comparison and benchmarking provide additional knowledge and help to improve particular business practice. There are several directions for further research: exploring controlling in companies in other countries in our neighbourhood and comparing it with companies in Serbia, developing controlling benchmarks, researching crisis controlling and sustainability controlling.

\section{References}

Angelakis,G., Theriou,N., Floropoulos,I.(2010). Adoption and benefits of management accounting practices: Evidence from Greece and Finland. Advances in Accounting, incorporating Advances in International Accounting 26, 87-96. www.elsevier.com/locate/adiac

Bienkowska ,A.(2013). Determinants of controlling effectiveness. Slovak Scientific Journal management: science and education, Vol .3, No 1. Faculty of Management Science and Informatics University of Zilina, Slovak Republic, pp. 9-13.

Bienkowska,A (2014). Redefining of the controlling concepts. Slovak Scientific Journal management: science and education, 2014, VOLUME 4 NO.1, Faculty of Management Science and Informatics University of Zilina, Slovak Republic, pp.5-9.

Boyns,T.,Edwards,J.R.(2006). The Development of Cost and Management Accounting in Britain. Handbook of Management Accounting Research 2:969-1034. Elsevier Ltd. Doi: 10.1016/S1751-3243(06)02020-7.

Retrieved from https://www.researchgate.net/publication/229175217

Chow,W.C., Duh,R-R., Xiao,Y.J.(2006).Management Accounting Practices in the People's Republic of China.Handbook of Management Accounting Research, Volume 2, Elsevier, 923-967, doi: 10.1016/S1751-3243(06)02019-0. 
Todorović-Dudić A. et al.: Contribution of controlling to business efficiency

Gerboth, T. (2000).Prozesscontrolling Der Nachste Schritt in einem prozessorientierten Controlling. Controlling.

Hahn, D.,Hungenberg, H. (2001).PuK: Planung und Kontrolle, Planungs- und Kontrollsysteme, Planungs-und Kontrollrechnung. Wertorientierte Controllingkonzepte, 6th edition. Wiesbaden.

Hammersmidth, G. (2002).Menagement Controlling. Wien, PKJ, Beograd.

Hazell, W. H.(1921). Costing for manufacturers. London: Nisbet.

Henning,D.A.,Moseley,R.L.(1970). Authority Role of a Functional Manager: The Controller.In: Adminsitrative Science Quarterly, Vol.15.

Hirch,B. Zur Lehre im Fach Controlling.(2003). In: Weber,J./Hirsch,B.(Eds.): Zur Zukunft der Controllingforschung: Empirie. Schnittstellen und Umsetzung in der Lehre. Wiesbaden.

Horvath, P.(2006). Controlling. 10th edition, Munich.

Horvath,P.(2009).Controlling,Vahlen,Munchen.

Küpper, H.-U. (2005).Controlling: Konzeption. Aufgaben, Instrumente, 4th edition, Stuttgart.

Küpper,H.-U,Wagenhofer,A.(2002). Vorwort der Herausgeber. In: Handwörterbch Unternehmensrechnung und Controlling, 4th edition, Stuttgart.

Mosiek, T.(2002). Interne Kundenorientierung des Controlling. Frankfurt.

Muehlen,M. (2002).Workflow - based Process Controlling. Berlin.

Napier, C.(2006). Accounts of Change: 30 Years of Historical Accounting Research. In: Accounting, Organizations and Society, Vol.31.

Niedermayr,R. (1994).Entwicklungsstand des Controlling: System. Kontext und Effizienz, Wiesbaden.

Osmanagić -Bedenik,N. (2007).Komparativna analiza prakse kontrolinga u Hrvatskoj. Zbornik ekonomskog fakulteta u Zagrebu, Vol.5,No1.

Osmanagić- Bedenik,N (2015). The Challenge of Controlling. International Journal of Industrial Engineering and Management (IJIEM), Vol. 6 No 4. Faculty of technical science University of Novi Sad, Serbia, pp. 153-163

Perović,V. (2007).Kontroling. Rodacomm, Novi Sad.

Perry-Keene, L. (1925). Budgetary control. Cost Accountant, IV, pp.402-406.

Preen, H. (1907).Reorganisation and costings. A book for manufacturers and merchants. London: Simpkin,Marshall, Hamilton, Kent \& Co.

Raith,D. (2014).Accounting \& Controlling How to account for what counts. Karl Franzens Universitat Graz. Retrived from https://www.researchgate.net/publication/259526450

Renteria,H.S. (2000). Controlling the Audit Process.

Schäffer,U.(2013). Management accounting research in Germany: from splendid isolation to being part of the international community.Published online:15 February 2013. DOI: 10.1007/s00187-013-0170-6 Retrieved from www.researchgate.net/publication/257338853

Schäffer,U., Binder,C.(2008). Controlling" as an academic discipline: the development of management accounting and management control research in Germanspeaking countries between 1970 and 2003. WHU-Otto Beisheim School of Management. Accounting History, Vol 13(1): 33-74, DOI: 10.1177/1032373207083926. www.sagepub.co.uk

Schäffer,U., Schmidt, A., Strauss, E.(2014). An old boys' club on the threshold to becoming a professional association: The emergence and development of the 
Todorović-Dudić A. et al.: Contribution of controlling to business efficiency

association of German controllers from 1975 to 1989. WHU - Otto Beisheim School of Management, Germany, Accounting History, Vol. 19(1-2) 133-169.

DOI: $10.1177 / 1032373213517867$

Siegwart, H. (1986).Controlling-Konzepte und Controller-Funktionen in der Schweiz, Controlling-Konzepte im internationalen Vergleich. 1.Kölner Kolloquium 15 Jahre AWW Köln, Freiburg.

Skousen,K.F.,Zimmer,R.K.(1970). Controllershiop Obsolescence: Fact or Fiction. In:Management Accounting, Vol.51.

Solomons, D. (1952). The historical development of costing. In: D. Solomons (Ed.). Studies in Costing. London:Sweet \& Maxwell, pp. 1-52.

Spillecke, D. (2006).Interne Kundenorientierung des Controllerbereichs: Messung Erfolgsauswirkungen - Determinanten, Wiesbaden.

Talha,M.,Fahd,K.,Raja,B.J., Seetharaman,J. A (2010). New Look At Management Accounting. The Journal of Applied Business Research Volume 26, Number 4, The Clute Institute. Retrieved from http://www.cluteinstitute.com/ojs/index.php/JABR/article/view/309

Todorović-Dudić,A.(2015): Model korporativnog kontrolinga kao instrument upravljanja industrijskim sistemima. Doktorski disertacija. Fakultet Tehničkih Nauka, Novi Sad. http://www.ftn.uns.ac.rs/1090566669/disertacija

Vuko,T., Ojvan,I. (2013). Controlling and business efficiency. Croatian Operational Research Review (CRORR), Vol. 4, pp.44-52.

Weber,J.,Schäffer,U.,Bauer,M. (2000). Controller und Manager im Team. Series Advanced Controlling, Vol.14. 